\title{
Pengaruh Dosis Kompos dan Frekuensi Penyiraman pada Pertumbuhan Bibit Sengon Laut (Paraserianthes falcataria, L.)
}

\author{
Petrus Tefa ${ }^{\mathrm{a}}$, Maria Roberto I. C. O. Taolin ${ }^{\mathrm{b}}$, Maria Afnita Lelang \\ ${ }^{a}$ Fakultas Pertanian, Universitas Timor, Kefamenanu, TTU - NTT, 85613, Indonesia \\ ${ }^{\mathrm{b}}$ Fakultas Pertanian, Universitas Timor, Kefamenanu, TTU - NTT, 85613, Indonesia, email: ricotaolin@ gmail.com \\ c Fakultas Pertanian, Universitas Timor, Kefamenanu, TTU - NTT, 85613, Indonesia, email: afnitalelang@ymail.com
}

\section{Article Info}

\section{Article history:}

Received 9 September 2015

Received in revised form 15 September 2015 Accepted 18 Oktober 2015

Keywords:

Dosis Kompos

Frekuensi Penyiraman

Sengon Laut

\section{Abstrak}

Penelitian ini bertujuan untuk mengetahui pengaruh dosis kompos dan frekuensi penyiraman terhadap pertumbuhan bibit sengon laut serta mengetahui dosis kompos dan frekuensi penyiraman yang tepat untuk pertumbuhan bibit sengon laut yang optimum. Penelitian mengunakan Rancangan Acak Kelompok (RAK) faktorial yang diulang tiga kali. Faktor pertama adalah dosis kompos yang terdiri dari tiga aras yaitu kontrol atau $0 \mathrm{~g}$ per polybag, $30 \mathrm{~g}$ per polybag dan $40 \mathrm{~g}$ per polybag. Faktor kedua adalah frekuensi penyiraman yang terdiri dari tiga aras yaitu dua kali sehari, satu kali sehari dan dua hari sekali. Hasil penelitian menunjukan tidak terjadi pengaruh interaksi antara dosis kompos dan frekuensi penyiraman terhadap semua parameter. Dosis kompos berpengaruh nyata pada parameter tinggi tanaman setiap waktu pengamatan, diameter batang setiap waktu pengamatan, berat segar bibit dan berat kering bibit. Frekuensi penyiraman berpengaruh nyata terhadap suhu tanah 60 HSS dan 90 HSS, tinggi tanaman 30 HSS, diameter batang 30 HSS dan 60 HSS. Dosis kompos $30 \mathrm{~g}$ per polybag adalah dosis optimum bagi pertumbuhan bibit sengon sedangkan penyiraman dua kali sehari adalah frekuensi penyiraman yang tepat bagi bibit sengon. (2016 dipubikasikan oleh Savana Cendana.

\section{Pendahuluan}

Sengon atau jeunjing merupakan jenis tanaman yang cepat tumbuh. Jenis tanaman ini dahulunya oleh masyarakat di daerah Jawa dan sekitarnya dimanfaatkan sebagai tanaman pelindung di perkebunan, seiring dengan semakin meningkatnya kebutuhan papan sebagai bahan baku untuk perumahan maka jenis ini dimanfaatkan untuk keperluan tersebut. Selanjutnya pemanfaatan jenis tersebut meluas untuk kayu pertukangan antara lain triplek, peti kemas, korek api, konstruksi ringan dan juga sebagai bahan baku untuk pembuatan pulp dan kertas. Menurut Martawidjaya et al., (1987) jenis sengon termasuk dalam kelas awet IV dan V, kelas kuat III dan IV dan memiliki berat jenis 0,33. Keawetan kayu jenis ini cukup baik, sehingga kayu sengon banyak dimanfaatkan oleh masyarakat sebagai bahan bangunan.

Secara ekologis pohon sengon dapat meningkatkan kualitas lingkungan seperti meningkatkan kesuburan tanah, memperbaiki tata air dan menciptakan iklim mikro (Anonimous, 1987). Hal ini disebabkan sifat morfologis dari famili legum yaitu memiliki perakaran yang sangat dalam dan serasah daun cepat melapuk. Berdasarkan kriteria tersebut, maka tanaman sengon banyak dikembangkan sebagai komoditas dalam pengusahaan hutan tanaman, baik dalam skala besar seperti Hutan Tanaman Industri (HTI), reboisasi maupun skala kecil yaitu banyak ditanam di kebun-kebun rakyat dengan sistem tumpangsari.

Pembibitan tanaman sengon biasa dilakukan pada musim panas sehingga pada awal musim penghujan bibit telah siap untuk ditanam di lapangan. Wilayah Nusa Tenggara Timur (NTT) umumnya dan Kabupaten Timor Tengah Utara (TTU) kususnya adalah wilayah lahan kering dengan permasalahan utama adalah ketersediaan air untuk berbagai usaha budidaya tanaman pada musim panas. Padahal menurut Maynard dan Orcott (1987), air adalah salah satu komponen fisik yang sangat vital dan dibutuhkan dalam jumlah besar untuk pertumbuhan dan perkembangan tanaman. Sebanyak $85-90 \%$ dari bobot segar sel-sel dan jaringan tanaman tinggi adalah air.

Kekurangan air dapat diatasi dengan cara meningkatkan efisiensi penggunaan air seperti pengaturan frekuensi penyiraman sesuai kebutuhan optimum tanaman. Doorenbos dan Kassam (1979) menyatakan bahwa untuk mempercepat pertumbuhan dan meningkatkan hasil tanaman perlu penyiraman sesuai kebutuhan air. Lingga (1986) menyatakan frekuensi penyiraman yang kurang tepat dapat berakibat kerusakan total bagi pertumbuhan dan perkembangan tanaman. Bila frekuensi penyiraman terlalu tinggi maka poripori makro dan mikro terisi oleh air sehingga pernafasan akar dapat tergaggu. Di lain pihak, bila frekuensi penyiraman terlalu rendah, maka tanaman akan mengalami kekurangan air dan bermuara pada stress air.

Selain pengaturan frekuensi penyiraman, media yang digunakan juga harus memiliki daya ikat air yang tinggi sehingga air siraman dapat dimanfaatkan seefisien mungkin oleh tanaman. Menurut Clark (1989) dalam Lesmanawati (2005), kompos bersifat hidrofilik sehingga dapat meningkatkan kemampuan tanah dalam memegang air dan mengandung unsur $\mathrm{C}$ yang relatif tinggi sehingga dapat menjadi sumber energi mikroba. Selanjutnya menurut Widianto (1996) dalam Dharmawan (2003), kompos merupakan bahan organik yan telah mengalami dekomposisi oleh mikroorganisme pengurai sehingga dapat dimanfaatkan untuk memperbaiki sifat-sifat tanah, disamping itu di dalam kompos terkandung hara-hara mineral yang berfungsi untuk penyediaan makanan bagi tanaman. Kompos merupakan bahan organik yang dapat berfungsi sebagai pupuk, Selain itu, kompos juga dapat memperbaiki sifat fisik tanah sehingga tanah menjadi remah dan pada gilirannya mikroba-mikroba tanah yang bermanfaat dapat hidup lebih subur.

Di lingkungan petani banyak tersedia bahan organik seperti pupuk kandang sapi, sekam padi, jerami dan hijauan lantoro. Hal ini berpotensi untuk dijadikan sebagai media pembibitan sengon. Permasalahannya adalah belum diketahui pengaruh dosis pupuk kompos dan frekuensi penyiraman terhadap pertumbuhan bibit sengon laut. Penelitian ini bertujuan untuk mengetahui pengaruh dosis kompos dan frekuensi penyiraman terhadap pertumbuhan bibit sengon laut serta mengetahui dosis kompos dan frekuensi penyiraman yang tepat untuk pertumbuhan bibit sengon laut yang optimum.

\section{Metode}

2.1 Waktu dan Tempat

Penelitian ini dilaksanakan pada bulan Mei sampai Agustus di kebun percobaan Fakultas Pertanian, Universitas Timor Kelurahan Sasi, Kecamatan Kota Kefamenanu, Kabupaten TTU. Topografi berbukit-bukit dengan ketinggian $\pm 400 \mathrm{~m} \mathrm{dpl}$, curah hujan $900-1,500 \mathrm{~mm}$ per tahun, suhu udara berkisar antara $27^{\circ} \mathrm{C}$ dan $\mathrm{pH}$ tanah netral $(6,5)(\mathrm{BPS}, 2007)$

\subsection{Rancangan Percobaan}

Penelitian mengunakan Rancangan Acak Kelompok (RAK) faktorial 3 x 3 yang diulang tiga kali. Faktor pertama adalah dosis kompos (K) yang terdiri dari tiga aras yaitu kontrol atau $0 \mathrm{~g}$ per polybag $\left(\mathrm{k}_{0}\right), 30 \mathrm{~g}$ per polybag $\left(\mathrm{k}_{1}\right)$ dan $40 \mathrm{~g}$ per polybag $\left(\mathrm{k}_{2}\right)$. Faktor kedua adalah frekuensi penyiraman $(\mathrm{F})$ yang terdiri dari tiga aras yaitu dua kali sehari $\left(\mathrm{f}_{1}\right)$, satu kali sehari $\left(\mathrm{f}_{2}\right)$ dan dua hari sekali $\left(\mathrm{f}_{3}\right)$. Kombinasi perlakuannya antara lain $\mathrm{k}_{0} \mathrm{f}_{1}, \mathrm{k}_{0} \mathrm{f}_{2}, \mathrm{k}_{0} \mathrm{f}_{3}, \mathrm{k}_{1} \mathrm{f}_{1}, \mathrm{k}_{1} \mathrm{f}_{2}, \mathrm{k}_{1} \mathrm{f}_{3}, \mathrm{k}_{2} \mathrm{f}_{1}$, $\mathrm{k}_{2} \mathrm{f}_{2}$ dan $\mathrm{k}_{2} \mathrm{f}_{3}$.

\subsection{Pelaksanaan Penelitian}

\section{a. Persiapan Benih}

Benih yang digunakan dalam penelitian ini adalah benih sengon laut yang diambil dari PT Timor Raya yang beralamat di Km 9 jurusan Kupang. Benih berasal dari pohon induk tanaman sengon yang memiliki sifat-sifat genetik yang baik, bentuk fisiknya tegak lurus dan tegar, tidak menjadi inang dari hama dan penyakit. Benih yang dibutuhkan dalam penelitian ini sebanyak 675 biji dengan benih cadangan sebanyak $10 \%$ sehingga jumlah benih yang disiapkan sebanyak 729 biji. Benih diseleksi dengan cara memilih biji yang memiliki kulit bersih, berwarna coklat tua, ukuran benih maksimum, tenggelam dalam air ketika benih direndam dan bentuk benih masih utuh.

b. Pembuatan Kompos

Kompos dibuat dalam bak atau kotak persegi empat yang terbuat dari papan kayu dengan lebar $1 \mathrm{~m}$ dan panjang 1,5 m. Bahan kompos berupa material organik dari sisa-sisa tanaman yang dicampur dengan kotoran ternak sapi. Sisa-sisa tanaman dicacah menggunakan parang hingga menjadi potongan kecil. Bahan organik yang sudah dicacah dimasukan ke dalam bak kayu kemudian dipadatkan isi seluruh bak kayu hingga penuh. Selanjutnya dilakukan penyiraman untuk memberikan kelembaban. Untuk mempercepat proses pengomposan maka ditambahkan starter microorganism pembusuk ke dalam tumpukan kompos. Setelah 24 jam, suhu tumpukan kompos akan naik hingga $65{ }^{\circ} \mathrm{C}$, dan dibiarkan keadaan panas ini hingga 4 hari. Selanjutnya kompos disiram air dan dibolak-balik untuk menurunkan suhu dan mempertahankannya pada pada kisaran $45-60{ }^{\circ} \mathrm{C}$ dan kelembaban pada $40-50 \%$. Pada kondisi ini penguapan relatif tinggi, untuk mencegahnya maka tumpukan kompos ditutup dengan terpal plastik, sekaligus melindungi kompos dari siraman air hujan.

c. Persiapan Lahan Pembibitan

Lahan dibersihkan dari gulma dan serta vegetasi lainnya. Lahan yang digunakan berukuran panjang 9,6 m dan lebar 3,5 m dengan luas 33,6 $\mathrm{m}^{2}$ Lahan dibagi dalam tiga blok dan pada masing-masing blok dibuat sembilan petak percobaan dengan ukuran panjang $50 \mathrm{~cm}$ dan lebar $40 \mathrm{~cm}$ sehingga secara keseluruhan terdapat 27 petak. Pembuatan petak percobaan menggunakan patok kayu dan tali raffia. Jarak antara petak $0,5 \mathrm{~m}$ dan jarak antara blok $1 \mathrm{~m}$. Pada setiap blok, petak dan tanaman sampel diberikan label menggunakan tiang bambu dan seng. Lahan percobaan kemudian diberikan naungan setinggi $2 \mathrm{~m}$ 
dengan bahan kayu dan alang-alang. Jika terjadi hujan maka lahan percobaan akan ditutup menggunakan plastik transparan.

d. Persiapan Media Tanam

Media tanam yang digunakan adalah campuran tanah, pasir dan kompos. Tanah dan pasir dicampur merata dengan perbandingan 2:1 yang selanjutnya akan dimasukan dalam polybag berukuran diameter $10 \mathrm{~cm}$ dan tinggi $20 \mathrm{~cm}$. Sebelum dimasukan dalam polybag, sebagian media tanam diberikan kompos dengan dosis sesuai perlakuan. Terdapat 225 polybag tidak diberikan kompos, 225 polybag diberikan kompos dengan dosis $30 \mathrm{~g}$ per polybag dan 225 polybag diberikan kompos dengan dosis $40 \mathrm{~g}$ per polybag. Polybag yang telah berisi media tanam kemudian disusun dalam petak-petak percobaan.

e. Penyemaian Benih

Benih disemaikan dalam bak kecambah plastik dengan media kecambah berupa campuran tanah, pasir dan pupuk kandang sapi. Sebelum disemaikan benih direndam dalam air panas dengan suhu $80^{\circ} \mathrm{C}$ selama 30 menit, setelah itu benih direndam kembali dalam air dingin selama 24 jam. Benih kemudian ditabur dalam larikan yang sudah dibuat sebelumnya pada media kecambah Jarak antara larikan $5 \mathrm{~cm}$ dengan kedalaman $2 \mathrm{~cm}$. Benih yang ditabur tidak saling tumpang tindih agar pertumbuhan kecambah tidak bertumpuk, selanjutnya benih ditutup dengan media kecambah. Penyiraman dilakukan pada pagi dan sore hari dengan menggunakan hand spayer.

f. Penyapihan

Penyapihan dilakukan setelah kecambah berumur 14 hari dengan cara mengangkat kecambah yang sehat dari media kecambah kemudian ditanam dalam polybag pada sore hari, setiap polybag ditanam satu tanaman sehingga dalam setiap petak percobaan terdapat 25 tanaman dengan jumlah keseluruhan 675 tanaman.

g. Penyiraman

Penyiraman dilakukan sesuai dengan perlakuan pada penelitian ini. Penyiraman menggunakan hand sprayer hingga tanaman berumur 20 hari setelah sapih (HSS), selanjutnya penyiraman menggunakan gembor Penyiraman dilakukan selama penelitian dengan frekuensi penyiraman yang berbeda. Sembilan petak percobaan disiram dua kali dalam sehari pada pagi dan sore hari. Sembilan petak percobaan disiram satu kali dalam sehari pada sore hari dan sembilan petak percobaan disiram satu kali setiap dua hari pada sore hari.

h. Penyulaman

Penyulaman dilakukan dengan cara mengganti bibit yang mati atau rusak dengan bibit cadangan yang telah disiapkan. Selama penelitian sebanyak 7 bibit yang disulam.

i. Penyiangan

Penyiangan terhadap gulma dilakukan dengan mencabutnya dan bila perlu dibantu dengan alat pencungkil, namun dilakukan hati-hati agar jangan sampai akar bibit sengon terganggu.

\subsection{Parameter Pengamatan}

a. Suhu Tanah

Pengukuran suhu tanah dilakukan tiga kali selama penelitian yakni $30 \mathrm{HSS}$ 60 HSS dan 90 HSS, menggunakan thermometer suhu tanah, dengan cara ditancapkan pada kedalaman tanah $5 \mathrm{~cm}$ selama 3 menit pada tiga titik untuk setiap petak. Pengukuran dilakukan pada siang hari pukul 12,00-14,00 WITA.

b. Tinggi Tanaman $(\mathrm{cm})$

Tinggi tanaman diukur dengan menggunakan penggaris pada lima tanaman sampel. Anakan diukur mulai dari leher akar yaitu batas antara batang dengan akar di atas permukaan tanah hingga pucuknya. Pengukurannya dilakukan pada saat bibit berumur 30 HSS, 60 HSS dan 90 HSS.

\section{c. Diameter Batang $(\mathrm{mm})$}

Pengukuran diameter batang dilakukan dengan menggunakan jangka sorong dengan cara menjepit pada bagian batang $(1 \mathrm{~cm}$ di atas pangkal batang) dari lima tanaman sampel. Pengukuran dilakukan pada saat bibit berumur 30 HSS, 60 HSS dan 90 HSS

d. Luas Daun $\left(\mathrm{cm}^{2}\right)$

Pengukuran luas daun dilakukan pada akhir penelitian (90 HSS) menggunakan metode fotografi dengan cara mengambil semua daun pada lima tanaman sampel pada tiap petak, kemudian daun dipotret menggunakan kamera digital. Luas area daun kemudian dihitung menggunakan program ImageJ versi 1.410 .

e. Panjang Akar $(\mathrm{cm})$

Panjang akar diukur dengan menggunakan penggaris pada lima tanaman sampel. Akar diukur mulai dari leher akar yaitu batas antara batang dengan akar hingga ujung akar. Pengukurannya dilakukan pada saat bibit berumur 90 HSS. f. Berat Segar Bibit (g)

Pengukuran berat segar bibit dilakukan pada semua organ lima tanaman sampel yang dilakukan pada saat bibit berumur 90 HSS. Pengukuran dilakukan dengan cara memisahkan tanaman dari media tanam, kemudian akar dibersihkan dari kotoran atau tanah yang menempel. Selanjutnya semua organ dibersihkan kemudian ditimbang berat segarnya, Penimbangan menggunakan timbangan analitik.

g. Berat Kering Bibit $(\mathrm{g})$

Pengukuran berat kering bibit dilakukan pada semua organ lima tanaman sampel yang dilakukan pada saat bibit berumur 90 HSS. Pengukuran dilakukan dengan cara menimbang semua organ tanaman setelah dikeringkan dalam oven dengan suhu $105{ }^{\circ} \mathrm{C}$ selama 24 jam. Penimbangan menggunakan timbangan analitik.

\subsection{Analisis Data}

Data hasil pengamatan kemudian dianalisis dengan menggunakan sidik ragam (Anova) Rancangan Acak Kelompok (RAK). Rata-rata perlakuan selanjutnya diuji lanjut dengan menggunakan Duncan Multiple Range Test (DMRT) dengan tingkat signifikasi 5\% sesuai petunjuk Gomez dan Gomez (2010). Analisis data menggunakan program SAS 9,1.

\section{Hasil dan Pembahasan}

3.1 Suhu Tanah

Suhu tanah terus meningkat selama penelitian dengan kisaran suhu antara 22,8-32,5 ${ }^{\circ} \mathrm{C}$. Hasil sidik ragam (Anova) menunjukkan tidak terjadi interaksi antara dosis kompos dan frekuensi penyiraman terhadap suhu tanah setiap waktu pengamatan. Dosis kompos tidak berpengaruh nyata terhadap suhu tanah setiap waktu pengamatan tetapi data pada Tabel 1. menunjukan bahwa saat pengamatan 30 HSS suhu tanah yang diberikan kompos dengan dosis $40 \mathrm{~g}$ cenderung lebih tinggi, saat pengamatan 60 HSS suhu tanah yang diberikan kompos dengan dosis $30 \mathrm{~g}$ cenderung lebih tinggi sedangkan saat pengamatan 90 HSS suhu tanah yang tidak diberikan kompos cenderung lebih tinggi.

Frekuensi penyiraman tidak pengaruh nyata terhadap suhu tanah saat 30 HST tetapi data Tabel 1. menunjukan bahwa suhu tanah yang disiram dengan frekuensi dua kali sehari dan satu kali sehari cenderung lebih tinggi dari suhu tanah yang disiram dengan frekuensi dua hari sekali. Pada pengamatan 60 HSS dan 90 HSS frekuensi penyiraman berpengaruh nyata dimana suhu tanah yang disiram dengan frekuensi dua hari sekali paling tinggi dan selalu berbeda nyata dengan suhu tanah yang disiram dengan frekuensi dua kali sehari maupun satu kali sehari.

\begin{tabular}{|c|c|c|c|c|c|}
\hline \multirow{2}{*}{$\begin{array}{c}\text { Waktu } \\
\text { Pengamatan }\end{array}$} & \multirow{2}{*}{$\begin{array}{c}\text { Dosis Kompos } \\
\text { (g/Polybag) }\end{array}$} & \multicolumn{3}{|c|}{ Frekuensi Penyiraman } & \multirow{2}{*}{ Rerata } \\
\hline & & Dua Kali Sehari & Satu Kali Sehari & Dua Hari Sekali & \\
\hline \multirow{4}{*}{30 HSS } & 0 & $22,8 \mathrm{a}$ & $22,8 \mathrm{a}$ & $22,9 \mathrm{a}$ & $22,8 \mathrm{a}$ \\
\hline & 30 & $22,8 \mathrm{a}$ & $22,9 \mathrm{a}$ & $22,8 \mathrm{a}$ & $22,8 \mathrm{a}$ \\
\hline & 40 & $23,2 \mathrm{a}$ & $23,1 \mathrm{a}$ & $23,2 \mathrm{a}$ & $23,2 \mathrm{a}$ \\
\hline & Rerata & $23,0 \mathrm{a}$ & $22,9 \mathrm{a}$ & $23,0 \mathrm{a}$ & $(-)$ \\
\hline \multirow{4}{*}{$60 \mathrm{HSS}$} & 0 & $28,6 \mathrm{abc}$ & $27,0 \mathrm{c}$ & $29,6 \mathrm{ab}$ & $28,4 \mathrm{a}$ \\
\hline & 30 & $28,0 \mathrm{abc}$ & $28,0 \mathrm{abc}$ & $29,8 \mathrm{a}$ & $28,6 \mathrm{a}$ \\
\hline & 40 & $27,8 \mathrm{bc}$ & $28,4 \mathrm{abc}$ & $28,5 \mathrm{abc}$ & $28,3 \mathrm{a}$ \\
\hline & Rerata & $28,2 \mathrm{~b}$ & $27,8 \mathrm{~b}$ & $29,3 \mathrm{a}$ & $(-)$ \\
\hline \multirow{4}{*}{$90 \mathrm{HSS}$} & 0 & $30,9 \mathrm{bc}$ & $31,2 \mathrm{~b}$ & $32,5 \mathrm{a}$ & $31,5 \mathrm{a}$ \\
\hline & 30 & $30,6 \mathrm{c}$ & $31,2 \mathrm{~b}$ & $32,1 \mathrm{a}$ & $31,3 \mathrm{a}$ \\
\hline & 40 & $30,1 \mathrm{~d}$ & $31,2 \mathrm{~b}$ & $32,4 \mathrm{a}$ & $31,2 \mathrm{a}$ \\
\hline & Rerata & $30,5 \mathrm{c}$ & $31,2 \mathrm{~b}$ & $32,3 \mathrm{a}$ & $(-)$ \\
\hline
\end{tabular}

\subsection{Tinggi Tanaman}

Pertambahan tinggi tanaman terus mengalami peningkatan pada setiap waktu pengamatan, besarnya pertambahan tinggi berbeda-beda untuk setiap perlakuan. Hasil sidik ragam (Anova) menunjukkan tidak terjadi interaksi antara dosis kompos dan frekuensi penyiraman terhadap tinggi tanaman setiap waktu pengamatan. Dosis kompos berpengaruh nyata terhadap tinggi tanaman setiap waktu pengamatan dimana tanaman yang diberikan kompos dengan dosis $30 \mathrm{~g}$ selalu paling tinggi dan berbeda nyata dengan tinggi tanaman yang tidak diberikan kompos. 
Tabel 2. Tinggi Tanaman $(\mathrm{cm})$

\begin{tabular}{|c|c|c|c|c|c|}
\hline \multirow{2}{*}{$\begin{array}{c}\text { Waktu } \\
\text { Pengamatan }\end{array}$} & \multirow{2}{*}{$\begin{array}{c}\text { Dosis Kompos } \\
\text { (g/Polybag) }\end{array}$} & \multicolumn{3}{|c|}{ Frekuensi Penyiraman } & \multirow{2}{*}{ Rerata } \\
\hline & & Dua Kali Sehari & Satu Kali Sehari & Dua Hari Sekali & \\
\hline \multirow{4}{*}{$30 \mathrm{HSS}$} & 0 & $3,2 \mathrm{bc}$ & $3,3 \mathrm{bc}$ & $3,3 \mathrm{c}$ & $3,3 \mathrm{~b}$ \\
\hline & 30 & $3,6 \mathrm{abc}$ & $3,8 \mathrm{bc}$ & $3,3 \mathrm{bc}$ & $3,5 \mathrm{a}$ \\
\hline & 40 & $3,3 \mathrm{bc}$ & $3,5 \mathrm{ab}$ & $3,2 \mathrm{a}$ & $3,3 \mathrm{~b}$ \\
\hline & Rerata & $3,4 \mathrm{ab}$ & $3,5 \mathrm{a}$ & $3,3 \mathrm{~b}$ & $(-)$ \\
\hline \multirow{4}{*}{$60 \mathrm{HSS}$} & 0 & $4,6 \mathrm{~cd}$ & $4,5 \mathrm{~d}$ & $5,0 \mathrm{bcd}$ & $4,7 \mathrm{~b}$ \\
\hline & 30 & $6,1 \mathrm{a}$ & $6,0 \mathrm{a}$ & $5,7 \mathrm{ab}$ & $5,9 \mathrm{a}$ \\
\hline & 40 & $6,1 \mathrm{a}$ & $5,4 a b c$ & $5,5 \mathrm{ab}$ & $5,7 \mathrm{a}$ \\
\hline & Rerata & $5,6 \mathrm{a}$ & $5,3 \mathrm{a}$ & $5,4 \mathrm{a}$ & $(-)$ \\
\hline \multirow{4}{*}{$90 \mathrm{HSS}$} & 0 & $9,8 \mathrm{~b}$ & $8,6 \mathrm{~b}$ & $9,8 \mathrm{~b}$ & $9,4 \mathrm{~b}$ \\
\hline & 30 & $14,8 \mathrm{ab}$ & $18,7 \mathrm{a}$ & $12,9 \mathrm{ab}$ & $15,5 \mathrm{a}$ \\
\hline & 40 & $14,1 \mathrm{ab}$ & $11,1 \mathrm{ab}$ & $13,3 \mathrm{ab}$ & $12,9 \mathrm{ab}$ \\
\hline & Rerata & $12,9 \mathrm{a}$ & $12,8 \mathrm{a}$ & $12,0 \mathrm{a}$ & $(-)$ \\
\hline
\end{tabular}

Frekuensi penyiraman berpengaruh nyata terhadap tinggi tanaman saat 30 HSS dimana tanaman yang disiram dengan frekuensi satu kali sehari paling tinggi dan berbeda nyata dengan tinggi tanaman yang disiram dengan frekuensi dua hari sekali, sedangkan saat 60 HSS dan 90 HSS frekuensi penyiraman tidak berpengaruh nyata terhadap tinggi tanaman tetapi data Tabel 3. menunjukkan bahwa tanaman yang disiram dengan frekuensi dua kali sehari selalu cenderung lebih tinggi.

\subsection{Diameter Batang}

Batang tanaman terus bertambah besar selama penelitian. Hasil sidik ragam (Anova) menunjukkan bahwa tidak terjadi interaksi antara dosis kompos dan frekuensi penyiraman terhadap diameter batang setiap waktu pengamatan

Tabel 3. Diameter Batang (mm)

\begin{tabular}{|c|c|c|c|c|c|}
\hline \multirow{2}{*}{$\begin{array}{c}\text { Waktu } \\
\text { Pengamatan }\end{array}$} & \multirow{2}{*}{$\begin{array}{l}\text { Dosis Kompos } \\
\text { (g/Polybag) }\end{array}$} & \multicolumn{3}{|c|}{ Frekuensi Penyiraman } & \multirow{2}{*}{ Rerata } \\
\hline & & Dua Kali Sehari & Satu Kali Sehari & Dua Hari Sekali & \\
\hline \multirow{4}{*}{$30 \mathrm{HSS}$} & 0 & $0,63 \mathrm{c}$ & $0,64 \mathrm{c}$ & $0,60 \mathrm{c}$ & $0,62 \mathrm{~b}$ \\
\hline & 30 & $0,78 \mathrm{a}$ & $0,73 \mathrm{ab}$ & $0,72 a b$ & $0,74 \mathrm{a}$ \\
\hline & 40 & $0,78 \mathrm{a}$ & 0,77 a & $0,66 \mathrm{bc}$ & $0,74 \mathrm{a}$ \\
\hline & Rerata & $0,73 \mathrm{a}$ & $0,71 \mathrm{a}$ & $0,66 \mathrm{~b}$ & $(-)$ \\
\hline \multirow{4}{*}{$60 \mathrm{HSS}$} & 0 & $1,79 \mathrm{~d}$ & $1,86 \mathrm{~d}$ & $1,87 \mathrm{~d}$ & $1,84 \mathrm{~b}$ \\
\hline & 30 & $3,04 \mathrm{a}$ & $2,58 \mathrm{abc}$ & $2,36 \mathrm{bcd}$ & $2,66 \mathrm{a}$ \\
\hline & 40 & $2,77 \mathrm{ab}$ & $2,02 \mathrm{~cd}$ & $2,71 \mathrm{ab}$ & $2,50 \mathrm{a}$ \\
\hline & Rerata & $2,54 \mathrm{a}$ & $2,15 \mathrm{~b}$ & $2,31 \mathrm{ab}$ & $(-)$ \\
\hline \multirow{4}{*}{90 HSS } & 0 & $3,07 \mathrm{~d}$ & $3,30 \mathrm{~cd}$ & $3,12 \mathrm{~d}$ & $3,16 \mathrm{~b}$ \\
\hline & 30 & $4,21 \mathrm{a}$ & $3,70 \mathrm{abc}$ & $3,80 \mathrm{abc}$ & $3,90 \mathrm{a}$ \\
\hline & 40 & $3,97 \mathrm{ab}$ & $3,45 \mathrm{bcd}$ & $3,86 a b c$ & $3,76 \mathrm{a}$ \\
\hline & Rerata & $3,75 \mathrm{a}$ & $3,48 \mathrm{a}$ & $3,59 \mathrm{a}$ & $(-)$ \\
\hline
\end{tabular}

$(-)$ : Tidak terjadi interaksi antar faktor

Dosis kompos berpengaruh nyata terhadap diameter batang setiap waktu pengamatan dimana batang tanaman yang diberikan kompos dengan dosis $30 \mathrm{~g}$ selalu paling besar dan berbeda nyata dengan diameter batang tanaman yang tidak diberikan kompos tetapi tidak berbeda nyata dengan diameter batang tanaman yang diberikan kompos dengan dosis $40 \mathrm{~g}$.

Frekuensi penyiraman berpengaruh nyata terhadap diameter batang saat 30 HSS dan 60 HSS dimana batang tanaman yang disiram dengan frekuensi dua kali sehari selalu paling besar dan berbeda nyata dengan diameter batang tanaman yang disiram dengan frekuensi dua hari sekali saat 30 HSS dan berbeda nyata dengan diameter batang tanaman yang disiram dengan frekuensi satu kali sehari saat 30 HSS, sedangkan saat 90 HSS frekuensi penyiraman tidak berpengaruh nyata terhadap diameter batang tetapi data Tabel 4 menunjukkan bahwa batang tanaman yang disiram dengan frekuensi dua kali sehari cenderung lebih besar.

\subsection{Luas Daun}

Hasil sidik ragam (Anova) menunjukan bahwa tidak terjadi interaksi antara dosis kompos dan frekuensi penyiraman terhadap luas daun. Dosis kompos tidak berpengaruh nyata terhadap luas daun tetapi data Tabel 5. menunjukkan bahwa permukaan daun tanaman yang diberikan kompos dengan dosis $40 \mathrm{~g}$ cenderung lebih luas sedangkan permukaan daun tanaman yang tidak diberikan kompos paling sempit.

\begin{tabular}{ccccc} 
Tabel 4. Luas Daun $\left(\mathrm{cm}^{2}\right)$ & \multicolumn{3}{c}{ Rerata } \\
\cline { 2 - 4 } Dosis Kompos & \multicolumn{3}{c}{ Frekuensi Penyiraman } \\
\cline { 2 - 4 } & Dua Kali Sehari & Satu Kali Sehari & Dua Hari Sekali & \\
\hline 0 & $54,6 \mathrm{~b}$ & $42,7 \mathrm{~b}$ & $75,1 \mathrm{~b}$ & $57,5 \mathrm{a}$ \\
30 & $143,3 \mathrm{ab}$ & $115,7 \mathrm{ab}$ & $140,7 \mathrm{ab}$ & $133,2 \mathrm{a}$ \\
40 & $340,6 \mathrm{a}$ & $62,7 \mathrm{~b}$ & $110,7 \mathrm{ab}$ & $171,3 \mathrm{a}$ \\
\hline Rerata & $179,5 \mathrm{a}$ & $73,7 \mathrm{a}$ & $108,8 \mathrm{a}$ & $(-)$ \\
\hline Keterangan $:$ & Angka pada baris dan kolom yang diikuti dengan huruf yang sama tidak berbeda nyata menurut uji DMRT @ 5\%. \\
& (-): Tidak terjadi interaksi antar faktor &
\end{tabular}

Frekuensi penyiraman juga tidak berpengaruh nyata terhadap luas daun tetapi permukaan daun tanaman yang disiram dengan frekuensi dua kali sehari cenderung lebih luas sedangkan permukaan daun tanaman yang disiram dengan frekuensi satu kali sehari paling sempit.

\subsection{Panjang Akar}

Hasil sidik ragam (Anova) menunjukan bahwa tidak terjadi pengaruh interaksi antara dosis kompos dan frekuensi penyiraman terhadap panjang akar. Dosis kompos tidak berpengaruh nyata terhadap panjang akar tetapi data Tabel
6. menunjukkan bahwa akar tanaman yang diberikan kompos dengan dosis $30 \mathrm{~g}$ cenderung lebih panjang sedangkan akar tanaman yang diberikan kompos dengan dosis $40 \mathrm{~g}$ paling pendek.

Frekuensi penyiraman juga tidak berpengaruh nyata terhadap panjang akar tetapi akar tanaman yang disiram dengan frekuensi dua kali sehari cenderung lebih panjang sedangkan akar tanaman yang disiram dengan frekuensi satu kali sehari paling pendek. 
Tabel 5. Panjang Akar (cm)

\begin{tabular}{|c|c|c|c|c|}
\hline \multirow{2}{*}{$\begin{array}{c}\text { Dosis Kompos } \\
\text { (g/Polybag) }\end{array}$} & \multicolumn{3}{|c|}{ Frekuensi Penyiraman } & \multirow{2}{*}{ Rerata } \\
\hline & Dua Kali Sehari & Satu Kali Sehari & Dua Hari Sekali & \\
\hline 0 & $34,7 \mathrm{a}$ & $34,4 \mathrm{a}$ & $35,5 \mathrm{a}$ & $34,9 \mathrm{a}$ \\
\hline 30 & $36,5 \mathrm{a}$ & $35,7 \mathrm{a}$ & $35,7 \mathrm{a}$ & $36,0 \mathrm{a}$ \\
\hline 40 & $35,4 \mathrm{a}$ & $32,5 \mathrm{a}$ & $35,1 \mathrm{a}$ & $34,3 \mathrm{a}$ \\
\hline Rerata & $35,5 \mathrm{a}$ & $34,2 \mathrm{a}$ & $35,4 \mathrm{a}$ & $(-)$ \\
\hline
\end{tabular}

\subsection{Berat Segar Bibit}

Hasil sidik ragam (Anova) menunjukan bahwa tidak terjadi interkasi antara dosis kompos dan frekuensi penyiraman terhadap berat segar bibit. Dosis kompos berpengaruh nyata terhadap berat segar bibit dimana bibit segar dari tanaman yang diberikan kompos dengan dosis $30 \mathrm{~g}$ paling berat dan berbeda nyata dengan berat segar bibit dari tanaman yang tidak diberikan kompos tetapi tidak berbeda nyata dengan berat segar bibit dari tanaman yang diberikan kompos dengan dosis $40 \mathrm{~g}$.

Frekuensi penyiraman tidak berpengaruh nyata terhadap berat segar bibit tetapi bibit segar yang disiram dengan frekuensi dua hari sekali cenderung lebih berat sedangkan bibit segar yang disiram dengan frekuensi satu kali sehari paling ringan.

\begin{tabular}{|c|c|c|c|c|}
\hline \multirow{2}{*}{$\begin{array}{c}\text { Dosis Kompos } \\
\text { (g/Polybag) }\end{array}$} & \multicolumn{3}{|c|}{ Frekuensi Penyiraman } & \multirow{2}{*}{ Rerata } \\
\hline & Dua Kali Sehari & Satu Kali Sehari & Dua Hari Sekali & \\
\hline 0 & $3,01 \mathrm{~cd}$ & $2,39 \mathrm{~d}$ & $3,96 \mathrm{bcd}$ & $3,12 \mathrm{~b}$ \\
\hline 30 & $5,86 \mathrm{abc}$ & 4,91 abcd & $6,02 \mathrm{ab}$ & $5,60 \mathrm{a}$ \\
\hline 40 & $6,89 \mathrm{a}$ & $3,91 \mathrm{bcd}$ & $5,79 \mathrm{abc}$ & $5,53 \mathrm{a}$ \\
\hline Rerata & $5,25 \mathrm{a}$ & $3,74 \mathrm{a}$ & $5,26 \mathrm{a}$ & $(-)$ \\
\hline
\end{tabular}

\subsection{Berat Kering Bibit}

Hasil sidik ragam (Anova) menunjukan bahwa tidak terjadi pengaruh interaksi antara dosis kompos dan frekuensi penyiraman terhadap berat kering bibit. Dosis kompos berpengaruh nyata terhadap berat kering bibit dimana bibit kering dari tanaman yang diberikan kompos dengan dosis $30 \mathrm{~g}$ paling berat dan berbeda nyata dengan berat kering bibit dari tanaman yang tidak diberikan kompos tetapi tidak berbeda nyata dengan berat kering bibit dari tanaman yang diberikan kompos dengan dosis $40 \mathrm{~g}$.

Frekuensi penyiraman tidak berpengaruh nyata terhadap berat kering bibit tetapi bahan kering bibit yang disiram dengan frekuensi dua kali sehari dan dua hari sekali cenderung lebih berat dibandingkan bahan kering bibit yang disiram dengan frekuensi satu kali sehari.

\begin{tabular}{ccccc}
\multicolumn{7}{l}{ Tabel 7. Berat Kering Bibit $(\mathrm{g})$} \\
\cline { 2 - 4 } $\begin{array}{c}\text { Dosis Kompos } \\
\text { (g/Polybag) }\end{array}$ & Dua Kali Sehari & Satu Kali Sehari & Dua Hari Sekali & \multirow{2}{*}{ Rerata } \\
\hline 0 & $0,8 \mathrm{bc}$ & $0,6 \mathrm{c}$ & $0,8 \mathrm{~b}$ \\
30 & $1,6 \mathrm{a}$ & $1,4 \mathrm{ab}$ & $1,0 \mathrm{abc}$ & $1,5 \mathrm{a}$ \\
40 & $1,7 \mathrm{a}$ & $0,9 \mathrm{abc} \mathrm{a}$ & $1,4 \mathrm{a}$ \\
\hline Rerata & $1,4 \mathrm{a}$ & $1,6 \mathrm{a}$ & $(-)$ \\
\hline Keterangan : & Angka pada baris dan kolom yang diikuti dengan huruf yang sama tidak berbeda nyata menurut uji DMRT @ 5\%.
\end{tabular}

\subsection{Pembahasan}

Pemberian kompos dengan dosis $30 \mathrm{~g}$ per tanaman memberikan pertumbuhan bibit sengon yang lebih baik berupa tanaman yang lebih tinggi dengan batang yang lebih besar, permukaan daunya tidak terlalu luas tetapi bibit sengon memiliki akar yang paling panjang dengan bahan segar tanaman maupun bahan kering tanaman yang lebih berat jika dibandingkan dengan bibit sengon yang tidak diberikan kompos maupun bibit sengon yang diberikan kompos dengan dosis $40 \mathrm{~g}$ per tanaman.

Penyiraman dengan frekuensi dua kali sehari memberikan pertumbuhan bibit sengon yang lebih baik berupa tanaman yang lebih tinggi dengan batang yang lebih besar, permukaan daunya paling luas, akar yang paling panjang walaupun bahan segar tanaman tidak terlalu berat tetapi bahan keringnya lebih berat dan sama dengan berat kering bibit yang disiram dengan frekuensi dua hari sekali.

\section{Simpulan}

Dari analisis hasil dan pembahasan yang dilakukan maka dapat disimpulkan beberapa hal sebagai berikut:

a. Tidak terjadi pengaruh interaksi antara dosis kompos dan frekuensi penyiraman terhadap semua parameter.

b. Dosis kompos berpengaruh nyata pada parameter tinggi tanaman setiap waktu pengamatan, diameter batang setiap waktu pengamatan, berat segar bibit dan berat kering bibit. Frekuensi penyiraman berpengaruh nyata terhadap suhu tanah 60 HSS dan 90 HSS, tinggi tanaman 30 HSS, diameter batang 30 HSS dan 60 HSS,

c. Dosis kompos $30 \mathrm{~g}$ per polybag adalah dosis optimum bagi pertumbuhan bibit sengon sedangkan penyiraman dua kali sehari adalah frekuensi penyiraman yang tepat bagi bibit sengon.

\section{Pustaka}

Akhmad F A, 2008, Pengaruh Dosis Pupuk Kandang Sapidan Interval Penyiraman Terhadap Pertumbuhanbibit Sengon (Paraserianthes falcataria (L) Nielson), [Internet], [diunduh 2015 Februari 07].
BPS TTU, 2007,Timor Tengah Utara Dalam Angka, BPS TTU, Kefamenanu, Doorenbos J dan A H Kassam, 1979, Yield Response to Water, FAO Irrigation and Drainage Paper 33, FAO, Rome,

Dharmawan IW, 2003, Pemanfaatan endomikoriza dan pupuk organik dalam memperbaiki pertumbuhan Gmelina arborea LINN pada tanah tailing [Tesis], Bogor: Program Pasca Sarjana, Institut Pertanian Bogor,

Gomez K A dan Gomez A A, 1995, Prosedur Statistik untuk Penelitian Pertanian, Edisi ke 2, Jakarta: UI Press,

Lendri, S, 2003, Teknik pembibitan mengkudu pada berbagai media: Buletin Teknik Pertanian 8(1): 5-7

Lesmanawati I, R, 2005, Pengaruh pemberian kompos, thiobacillus, dan penanaman gmelina serta sengon pada tailing emas terhadap biodegradasi sianida dan pertumbuhan kedua tanaman [Tesis], Bogor: Program Pasca Sarjana, Institut Pertanian Bogor.

Lingga, 1986, Petunjuk Penggunaan pupuk, Penebar Swadaya, Jakarta,

Martawijaya, A, I, Kartasujana, 1977, Ciri Umum, Sifat dan Kegunaan JenisJenis Kayu Indonesia, Publikasi Khusus No, 41, LPHH, Bogor,

Martawijaya A, I Kartasurjana, Y Mandang, SA Prawira, K Kadir, 1987, Atlas Kayu Indonesia Jilid II, Bogor: Balai Penelitian Hasil Hutan,

Maynard GH dan DM Orcott, 1987, The Physiology of Plants Under Stress, John Wiley and Sons, Inc, New York,

Muswita, Murni dan Herlina L, 2008, Pengaruh Pupuk Organik Terhadap Pertumbuhan Sengon (Albizia falcataria (L,) Fosberg), J, Universita Jambi,

Warisno dan Dahana K, 2009, Investasi Sengon, PT Gramedia Pustaka Utama, Jakarta

Wasis, B, dan Agustina, S (2011), Pengaruh Pemberian Kompos Terhadap Pertumbuhan Semai Mahoni (Swietenia macrophylla King) pada Media Tanah Bekas Tambang Emas (Tailing), Jurnal Sivikultura Tropika, 3 (1), 109-112. 